\title{
Author Correction: Engineering-enhanced CAR T cells for improved cancer therapy
}

Michael C. Milone, Jie Xu, Sai-Juan Chen, McKensie A. Collins, Jianfeng Zhou, Daniel J. Powell Jr(D) and J. Joseph Melenhorst (iD

Correction to: Nature Cancer https://doi.org/10.1038/s43018-021-00241-5, published online 19 August 2021.

In the version of this Review initially published, an error appeared in the spelling of the fifth author's name. Specifically, author "Jianfeng Zhou" mistakenly appeared as "Jiafeng Zhou" in the originally published version. This has been corrected in the online version of the Review.

Published online: 24 September 2021

https://doi.org/10.1038/s43018-021-00277-7

๑ Springer Nature America, Inc. 2021 